\begin{tabular}{lc|} 
UAD & ADJES (Ahmad Dahlan Journal of English Studies) \\
VOL 8, No. 1, 59-67 \\
$\begin{array}{l}\text { Universitas } \\
\text { Ahmad Dahlan }\end{array}$ \\
https://doi.org/10.26555/adjes.v8i1.20095
\end{tabular}

\title{
A Descriptive Review of Genre-Based Pedagogy Studies (Towards Genre Awareness in EFL Context of Indonesia)
}

\section{Tri Rina Budiwati}

Email : tri.budiwati@enlitera.uad.ac.id

Universitas Ahmad Dahlan, Yogyakarta, Indonesia

\section{ARTICLE INFO}

Article history

Received: 21 February 2021

Revised: 3 March 2021

Accepted: 17 March 2021

Keywords

review of genre

genre awareness

EFL context

Indonesia

\section{ABSTRACT}

This paper reviews 11 studies on genre-based pedagogy. The studies have indicated the vital contribution of genre knowledge in EFL context, especially in reading and writing class. Having compared and highlighted the 11 studies, this recent review reveals the great significance of genre knowledge and awareness for EFL teachers and students, namely, they can help students understand genre as created, dynamic and ideological structures, aware of generic structure of texts, then create various type of texts as discourse, develop the rhetorical understanding and participate in the genres, that they can maintain the critical genre awareness. Furthermore, teachers also are more aware that students can create meanings and need supports. The review, then, proposes some ways to improve students' genre awareness that could be applied in EFL classes. The ways are (1) students can be asked to analyze genre gradually to learn the techniques of rhetorical analysis of various genres; (2) students are asked to criticize and practice writing flexibly various genres based on certain rhetorical patterns, context, and purpose; and (3) in exposing genres, teachers could do the steps recommended, such as finding the purpose and features, language scaffolding, modeling, joint instruction of the text, individual construction of the text, peer review and revision, free discussion and doing the assignment.

This is an open access article under the $\mathrm{CC}-\mathrm{BY}-\mathrm{SA}$ license.

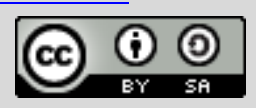

\section{Introduction}

Nowadays, genre becomes one of the prominent topics in linguistics and language teaching. In this case, Hyland (in Millar, 2011: 3) argued that "today, genre is one of the most important and influential concepts in literacy education". In the last decades, various studies on genre analysis have been conducted significantly in multiple contexts. Bawarshi and Reiff (2010: viii-ix) listed genre research in numerous settings, such as academic, workplace and professional, public, and media contexts. They also showed significant genre approaches in teaching (especially reading and writing). 
In Indonesia's context, a genre-based approach has been applied in the curriculum 2013 and/or the revision of curriculum 2013. It is stated that:

"Pengajaran bahasa di tingkat SMA/MA, seperti di SMP, masih berfokus pada peningkatan kompetensi peserta didik untuk mampu menggunakan bahasa tersebut untuk mencapai tujuan komunikasi dalam berbagai konteks, baik lisan maupun tulis dengan kompleksitas yang lebih tinggi dari materi yang dipelajari di SMP, dengan menggunakan pendekatan yang sama, yaitu pendekatan berbasis teks. Pembelajaran ini adalah pembelajaran yang mengacu pada fungsi bahasa dan penggunaannya, yang merupakan satu kesatuan makna baik lisan maupun tulis. Adapun yang dimaksud dengan teks adalah kesatuan makna yang dapat terdiri atas satu kata seperti kata 'stop' di pinggir jalan, satu frase 'no smoking', satu kalimat berupa pengumuman sampai satu buku. Dengan demikian, pembelajaran berbasis genre sangat relevan untuk diterapkan" ("Silabus Mata Pelajaran Bahasa Inggris Sekolah Menengah Atas/Madrasah Aliyah (SMA/MA)”, 2019, para. 2).

('Language learning in senior high schools, as in junior high schools, focuses on students' competence improvement to be able to use language to achieve communicative goals in various contexts, either spoken or written, in more complexities than of which are studied in junior high schools, by using the same approach, that is text-based approach. This is language learning which refers to the language function and use. Text is the unified meaning which can consist of one word as in 'stop', one phrase 'no smoking', a sentence, like an announcement or one book. Therefore, genre-based learning is very relevant to be applied").

This paper reviews 11 studies which focused on genre-based pedagogy theoretically and practically, especially in EFL classroom. The studies give various concept understanding and practical application of genre awareness in ESL and EFL reading and writing classroom. Devitt (2009), Millar (2011), Du (2015) discussed how to teach, promote, and raise critical genre awareness. Abbaszadeh (2013) focused on understanding the development of genre-based approach and its application in language teaching (especially in second language syllabus design). Yasuda (2011), Yayli (2011), Wang (2013) had conducted almost same observations on how to develop students' genre awareness in EFL context. Meanwhile, Wingate (2012) discussed the theoretical understanding and practical experience of genre-based models for writing class in London-England and Collin (2013) applied the same model in USA. The application genre-based approach on EFL classroom had been conducted by Rozimela (2014) who looked at the relationship between genre awareness and reading comprehension and by Uzun (2017) who found out the relationship between genre knowledge and writing performance.

Based on Azar's and Hashim's classification (2014), this review is categorized into academic review, especially the bibliographic review article which provides readers a comprehensive and descriptive record of annual works and it encompasses the literature-oriented approach. Azar and Hashim added that academic review genre provides an overview of the literature in the related fields or sub-fields and plays an important role in the life of academic researchers and scientific 
community members, and these types of reviews particularly the review article carries out distinctive functions. The bibliographic review article is dealt with a limited subject area and its text type is narrative and it may consist of a summary of findings or it can be indicative (i.e. merely in narrative form) or informative (i.e. providing an overview from a variety of publications in that subject with little criticism). The intended audiences of this type of review are researchers and graduate EFL students. Additionally, there are four main purposes for the bibliographic review article, such as: (1) to become literature-oriented, (2) to raise awareness of researchers and graduate students in their own present activity and related field, (3) to inform the missing work in that field, and (4) to give an overview of the subject.

Accordingly, this review will explore those earlier studies that indicate the vital contribution of genre knowledge in EFL context and reveals the great significance of genre awareness for both EFL teachers and students. Then, based on the EFL context of Indonesia, it also proposes some ways to improve students' genre awareness that could be applied in EFL classes.

\section{Genre, Genre Knowledge, and Genre Awareness}

Generally, genre is defined as "text type' and as "an artificial system of classification" (Bawarshi and Reiff, 2010: 4). However, in the last decades, genre has been defined in various perspectives by many scholars. Genre, as stated by Swales (1990: 58) “...comprises a class of communicative events, the members of which share some set of communicative purposes". From this definition, it is understood that genre deals with members of a linguistic community who have the same communicative goals. Millar (2011: 4) said that a particular genre has a certain discourse structure, following a series of "steps" or "moves" to reach the communicative goals. For example, a recipe consists of some moves like the name of the dish, a list if ingredients and amounts, the steps for cooking, etc. Furthermore, Devitt (2009: 348) defines genre as "rhetorical and social actions developing within particular social and cultural contexts". The notion stated by Devitt leads to awareness on a particular context in understanding text type.

Meanwhile, genre knowledge means "the type of knowledge required to communicate within a discourse community" (Uzun, 2017: 153). In addition to that, Uzun also stated that one should employ the resources, which is called genre knowledge, to respond appropriately to a particular discourse community (2017: 154). Based on Tardy's statement, Uzun (Ibid) quoted that genre knowledge includes formal, process, rhetorical, and subject-matter knowledge. Then, Uzun emphasized that genre knowledge is "multi-faceted, having linguistic, social and disciplinary levels" (Ibid). Therefore, unavoidably, this knowledge is very significant for teachers and students concerned with text and discourse in their daily academic lives.

Dealing with that, Millar (2011: 2) said that "genre awareness is the ability to select and use an appropriate genre based on some factors, including the purpose of communication, the context, 
and the people involved". Then Millar (2011: 6-7) added that the activities of genre awareness demand the students to observe how language works relating to the context.

\section{Method}

The corpus used in the review were 1 book chapter (Genre in a Changing World) and 10 articles published in established international journals between 2009 to 2017. The selected journals are English Teaching Forum, Journal of Second Language Writing, Journal of English for Academic Purposes, Journal of Adolescent and Adult Literacy, Journal of Theory and Practice in Language Studies, Procedia - Social and Behavioral Sciences 84, International Journal of Social Science, Creative Education, and The Journal of Teaching English for Specific and Academic Purposes. The reputation of the journals in publishing articles on genre, pedagogic subjects, and applied linguistics was taken into account for their impact factor.

The first step was to identify and understand the concept argued in the 11 articles to classify whether they were theoretical or practical studies. Among 11 articles, there were 3 theoretical studies (Devitt's, Millar's, and Collin's), and 8 practical studies (Yasuda's, Yayli's, Wingate's, Wang's, Abbaszadeh's, Rozimela's, Du's, and Uzun's).

The second step was to understand the contents, get the main points and draw the inference to indicate the important contribution of genre knowledge in EFL context and to show the great significance of genre awareness for both EFL teachers and students. This can be done by comparing and highlighting the main points in the 11 articles.

The third step was to propose some ways to improve students' genre awareness that could be applied in EFL classroom based on the EFL context of Indonesia.

\section{Discussion}

\section{Previous Studies on Genre-Based Pedagogy}

The paper was encouraged by special attention in genre-based researches in pedagogy conducted by many scholars, such as Devitt (2009), Millar (2011), Yasuda (2011), Yayli (2011), Wingate (2012), Wang (2013), Collin (2013), Abbaszadeh (2013), Rozimela (2014), Du (2015), and Uzun (2017).

Devitt (2009) argued that "Genres will impact students as they read, write, and move about their worlds, then teaching critical genre awareness will help students perceive the impact of genre and make deliberate generic choices". Besides, he also suggested that students' critical stance and their own agency through disciplinary discourse and academic writing can be maintained by critical genre awareness (Devitt, 2009: 337). Specifically, Devitt mentioned the genre awareness he meant is a type of rhetorical awareness that can lead to critical awareness and more thoughtful action (Devitt, 2009: 337). Then, Devitt explored teaching specific genres, 
suggested an alternative in teaching antecedent genres and proposed how to teach genre awareness (Devitt, 2009: 338 - 349). Dealing with that, Millar (2011: 6) also discussed teaching genres, challenges for EFL teachers, and how genre awareness is promoted in the EFL classroom. Millar (2011: 6-7) argued that genre awareness activities ask students to observe how language works relating to the context. In this case, Millar suggested activities that focus on three levels: genre and context, genre and discourse, and genre and language (2011: 7-9). Millar proposed some steps for each of these activities.

Yasuda (2011: 111) has conducted a research to investigate how novice foreign language (FL) writers develop their genre awareness, linguistic knowledge, and writing competence in a genrebased writing course among Japanese undergraduate students. To do so, Yasuda referred to systemic functional linguistics (SFL) and linked genre to task. Yasuda's research depicted that students' genre awareness and perceptions developed, then were noticeable in their actual written products. Additionally, Yasuda (2011: 127-129) provided examples of prototypical genre models and sample pedagogical tasks. Another study in an EFL context was also conducted by Yayli (2011). Yayli's observation aimed at finding how genre awareness becomes implanted in students' stances through genre-based instruction and how feasible multi-genre portfolio use in genre-based instruction in an EFL context (2011: 121-122). The result of Yayli's study showed that some of the participants have a genre awareness and recontextualize their genre awareness in each new writing and they also use certain generic features in a certain genre while being connected in another genre (cross-genre awareness) (2011: 121). Besides, it is also understood that cross-genre awareness is well functioned through the use of multi-genre portfolios in genrebased writing instruction (Yayli, 2011: 128).

The next study was done by Wingate (2012: 26), who used academic literacies and genrebased models for academic writing instruction in UK and argued that "the analysis of disciplinespecific texts is the best starting point for teaching and learning of academic writing, and the students will be more willing to take a critical perspective when they are able to understand and control disciplinary discourses". Then, Wang (2013: 2128) also conducted a study on the effectiveness of SFL-based genre approach in fostering EFL writer's genre awareness and writing competence in a 16-week semester in a college in China. Wang concluded that the genre approach has great contribution in provoking the writers' genre awareness, developing holistic writing quality, and improving lexical intensity.

Collin (2013: 215) suggested teachers apply rhetorical approach to the study of genre through Common Core Writing Standards, a writing standard made by a Common Core State Standards project in the USA. In this case, Common Core promotes a rhetorical concept in writing, that is a study on the effectiveness of the communication type in a different field. To conclude, Collin 
(2013: 221) remarked that a rhetorical approach to the study of genre could accommodate teachers and students to Core concerns of audience, purpose, task, and disciplinary thought. In addition to that, it can "help students learn to use different forms of communication to participate effectively in different situations".

In line with that, Abbaszadeh (2013: 1879) also attempted to present the significant role of genre study in language teaching, especially in second language syllabus design. Specifically, Du (2015: 631) proposed ESP writing lesson plan which "describes tasks and activities in great detail following a process-genre approach of teaching and learning" to raise process-genre awareness.

Furthermore, Rozimela (2014: 460) studied the relationship between students' genre awareness and their reading comprehension of different text types, in which she found the fact that the students' good genre awareness is related to good reading comprehension. Besides, students' reading comprehension is also influenced by background knowledge about the content of the text and field-related vocabulary. Whereas, Uzun (2017: 153,160) also studied the relationship between genre knowledge and writing performance which is indicated in the content, organization, vocabulary, and language use scores within the context.

In short, it is very obvious that the previous studies indicate the important contribution of genre knowledge in EFL context, especially in reading comprehension and writing performance and show the great significance of genre awareness for both EFL teachers and students.

\section{Contribution of Genre Knowledge in EFL Context}

From the previous studies, some contributions can be pondered. They are: (1) to help students perceive that impact and make deliberate generic choices (Devitt, 2009, 337); (2) to help students maintain a critical stance and their own agency through disciplinary discourse and academic writing (Devitt, 2009: 337); (3) students can keep a distance from the everyday practices of the genres that surround them but also can act, can participate in those genres (Devitt, 2009: 338); (4) seeing genre as things, processes, and contexts will help students to understand genres as created, dynamic, and ideological constructs (Devitt, 2009: 348); (5) to assist students in developing the rhetorical flexibility necessary for adapting their socio-cognitive genre knowledge to ever-evolving contexts (Johns in Millar, 2011: 7); (6) to assist students both to create text and reflect on writing by helping them to focus on how a text works as discourse (Hyland in Millar, 2011: 7); (7) to increase an awareness of generic structure of texts so that learner could learn to produce highly textures texts to achieve their communicative goals (Yayli, 2011: 128); (8) teachers become more aware of how students create meanings and more sensitive to the points where students need support (Yayli, 2011: 128), and (9) to enable the writer of a text to identify its type and choose the strategies that would best suit the purpose of the text (Olive in Uzun, 2017: 154). 
From the contributions of genre knowledge stated above, it can be understood that genre knowledge can help students understand genre as created, dynamic and ideological structures, aware of generic structure of texts, then create various type of texts as discourse, develop the rhetorical understanding and participate in the genres, that they can maintain the critical genre awareness. Furthermore, teachers also are more aware that students can create meanings and need supports.

\section{Alternative Ways to Improve Students' Genre Awareness}

Here are some ways to improve students' genre awareness from previous studies.

\section{a. Devitt's Projects}

Devit (2009: 349) proposed seven projects to help students gain a critical genre awareness; they are (1) project 1: to analyze a familiar, everyday genre as a class, learning the techniques of rhetorical analysis; (2) project 2: to write that familiar genre differently, with a major shift in the treatment of purpose, audience, subject, or setting; (3) project 3: to analyze a genre from another culture or time, working in groups to gather samples, analyze the genre, and learn about the historical or cultural context; (4) project 4: to analyze an academic genre chosen as a potential antecedent genre, working as a class on a common genre; (5) project 5: writing the academic genre within a specific writing task for this class; (6) project 6: critiquing that genre and recommending specific changes that might better meet each student's needs, and (7) project 7: analyzing, critiquing, and writing flexibly another potential antecedent genre.

b. Millar's Steps

Millar (2011: 7-9) proposed a range of activities that focus on three levels: (1) genre and context awareness activities which focus on text/audience/purpose activity, (2) genre and discourse awareness activities which focus on problem/solution activity, and (3) genre and language awareness activities which focus on spoken vs. written language activity. Each of the activities has its own steps based on the focus.

c. Yasuda's Examples

Yasuda (2011: 126-129) suggested that "genre instruction might offer a metalinguistic tool to explore another language further to make the same or similar meaning". To do so, Yasuda gave examples of prototypical genre models (e.g. Formal and informal emails), sample pedagogic tasks (e.g. Writing an email to certain person (s) with specific purpose (s)), prompts for the target tasks (e.g. Doing assignments), and sample survey questions and scale descriptors based on various criteria.

d. Du's Procedures

Du recommended the following steps: (1) step 1: discovering the goal and the features $(30$ minutes); (2) step 2: language (vocabulary and sentence structure) scaffolding (20 minutes); 
(3) step 3: modeling (5 minutes), (4) step 4: mutual/joint construction of the text (10 minutes);

(5) step 5: individual construction of the text (5 minutes); (6) step 6: peer review and revision (10 minutes), and (7) step 7: summary, free discussion, Q \& A (5 minutes) and assignment (5 minutes).

\section{Ways to Improve Genre Awareness in EFL Context of Indonesia}

Based on the projects, steps, procedures and examples recommended in the previous studies, it is understood that the alternative ways to improve students' genre awareness in EFL context of Indonesia could be proposed as follows: (1) students can be asked to analyze genre gradually from familiar to unfamiliar one, informal to formal, non-academic to academic and from Indonesian culture to another culture that they can learn the techniques of rhetorical analysis of various genres; (2) students are asked to criticize and practice writing flexibly various genres based on certain rhetorical patterns, context, and purpose; and (3) in exposing genres, teachers could do the steps recommended by $\mathrm{Du}$, such as finding the purpose and features, language scaffolding, modeling, joint instruction of the text, individual construction of the text, peer review and revision, free discussion and doing the assignment.

\section{Conclusion}

The contribution of genre knowledge in EFL context is obvious and evident. The ways to improve students' genre awareness recommended by some scholars in the previous studies and proposed could conceptually and practically be applied in ESL and EFL contexts. However, the challenges could appear in implementing genre-based teaching and learning processes, and then further study could be conducted to overcome them.

As an academic review, especially the bibliographic review, this article provides readers a comprehensive and descriptive overview of the literature in the genre-based pedagogic studies and could become literature-oriented and raise awareness of researchers and graduate students in their own present activity and related field. Next, this review is expected to be one of references for further studies on genre-based pedagogy and its implementation in EFL context of Indonesia.

\section{References}

Abbaszadeh, Z. (2013). Genre-based approach and second language syllabus design. Procedia Social and Behavioral Sciences, 84, 1879-1884. https://doi.org/10.1016/j.sbspro.2013.07.052

Azar, A. S., \& Hashim, A. (2014). Towards an analysis of review article in applied linguistics: Its classes, Purposes and characteristics. English Language Teaching, 7(10), 76-88. https://doi.org/10.5539/elt.v7n10p76

Bawarshi, A. S. \& Mary Jo Reiff. (2010). Genre an introduction to history, theory, research, and pedagogy. Indiana: Parlor Press LLC.

Collin, R. (2013). How rhetorical theories of genre address common core writing standards. 
Journal of Adolescent and Adult Literacy, Vol. 57, No. 3 (November 2013), page 215-222. https://www.jstor.org/stable/24034666

Devitt, A. (1993). 17 teaching critical genre awareness. 337-351.

Devitt, A. (2009) "Teaching critical genre awareness" genre in a changing world. Bazerman, C, Bonini, A, and Figueiredo (editors). Indiana: Parlor Press.

$\mathrm{Du}, \mathrm{B}$. (2015). Raising process-genre awareness: A proposal of ESP writing lesson plan. Creative Education, 06(06), 631-639. https://doi.org/10.4236/ce.2015.66062

Millar, D. (2011). Promoting genre awareness in the EFL classroom. English Teaching Forum, 49(2), 2-15. http://eric.ed.gov/?q=\%22genre\%22+\%22efl\%22\&id=EJ962379

Rozimela, Y. (2014). “The students' genre awareness and their reading comprehension of different text types". International Journal of Asian Social Science, 2014, 4 (4): 460-469. ISSN (e) 2224-4441. http://www.aessweb.com/journals/5007

Swales, J. M. (1990). Genre analysis English in academic and research settings. Cambridge: Cambridge University Press.

Uzun, K. (2017). The relationship between genre knowledge and writing performance. 5(2), 153162. https://doi.org/10.22190/JTESAP1702153U

Wang, C. (2013). A study of genre approach in EFL writing. Theory and Practice in Language Studies, 3(11), 2128-2135. https://doi.org/10.4304/tpls.3.11.2128-2135

Wingate, U. (2012). Using academic literacies and genre-based models for academic writing instruction: A "literacy" journey. Journal of English for Academic Purposes, 11(1), 26-37. https://doi.org/10.1016/j.jeap.2011.11.006

Yasuda, S. (2011). Genre-based tasks in foreign language writing: Developing writers' genre awareness, linguistic knowledge, and writing competence. Journal of Second Language Writing, 20(2), 111-133. https://doi.org/10.1016/j.jslw.2011.03.001

Yayli, D. (2011). From genre awareness to cross-genre awareness: A study in an EFL context. Journal of English for Academic Purposes, 10(3), 121-129. https://doi.org/10.1016/j.jeap.2011.02.001

"Silabus Mata Pelajaran Bahasa Inggris Sekolah Menengah Atas/Madrasah Aliyah (SMA/MA)", Retrieved August 26, 2019, from http://lexminanderdoda.blogspot.com/2016/11/silabusmapel-bahasa-inggris-program.html 